OPEN ACCESS

Edited by:

Iduna Arduini,

University of Pisa, Italy

Reviewed by:

Reinhard Turetschek,

Independent Researcher, Getzersdorf,

Austria

Daniel Roberts,

The University of Tennessee,

Knoxville, United States

*Correspondence:

Chiara Pucciariello

chiara.pucciariello@santannapisa.it;

c.pucciariello@sssup.it

Specialty section:

This article was submitted to

Plant Abiotic Stress,

a section of the journal

Frontiers in Plant Science

Received: 03 December 2018

Accepted: 18 April 2019

Published: 08 May 2019

Citation:

Pucciariello C, Boscari A,

Tagliani A, Brouquisse $R$ and Perata $P$ (2019) Exploring Legume-Rhizobia Symbiotic Models for Waterlogging Tolerance. Front. Plant Sci. 10:578.

doi: 10.3389/fpls.2019.00578

\section{Exploring Legume-Rhizobia Symbiotic Models for Waterlogging Tolerance}

\author{
Chiara Pucciariello ${ }^{*}$, Alexandre Boscari ${ }^{2}$, Andrea Tagliani ${ }^{1}$, Renaud Brouquisse ${ }^{2}$ and \\ Pierdomenico Perata ${ }^{1}$
}

1 PlantLab, Institute of Life Sciences, Sant'Anna School of Advanced Studies, Pisa, Italy, ${ }^{2}$ Institut Sophia Agrobiotech, Centre National de la Recherche Scientifique, Institut National de la Recherche Agronomique, Université Côte d'Azur, Nice, France

Unexpected and increasingly frequent extreme precipitation events result in soil flooding or waterlogging. Legumes have the capacity to establish a symbiotic relationship with endosymbiotic atmospheric dinitrogen-fixing rhizobia, thus contributing to natural nitrogen soil enrichment and reducing the need for chemical fertilization. The impact of waterlogging on nitrogen fixation and legume productivity needs to be considered for crop improvement. This review focuses on the legumes-rhizobia symbiotic models. We aim to summarize the mechanisms underlying symbiosis establishment, nodule development and functioning under waterlogging. The mechanisms of oxygen sensing of the host plant and symbiotic partner are considered in view of recent scientific advances.

Keywords: hypoxia, legumes, nitric oxide, oxygen sensing, symbiosis, waterlogging

\section{INTRODUCTION}

Global population is expected to reach around 9.6 billion in 2050 (Gerland et al., 2014), leading to a rise in the demand for food. Food issues are also aggravated by unexpected and increasingly frequent extreme weather events connected to climate change such as soil flooding or waterlogging, occurring especially in areas close to watercourses, characterized by poor soil drainage or exposure to monsoons.

In agriculture, the conversion to alternative, more ecologically sustainable sources is moving toward productive systems that reduce the input of fertilizers. Nitrogen $(\mathrm{N})$ is one of the most important nutrients for crops and today a reduction in crop dependence on chemical $\mathrm{N}$ fertilization is essential. This is due to the cascade of environmental changes resulted from the huge increase of ammonia $\left(\mathrm{NH}_{3}\right)$ production in the last century, such as water and soil pollution (Erisman et al., 2008). Legumes are well known for their agronomical and food properties, thanks to their capacity to establish a symbiotic relationship with endosymbiotic atmospheric dinitrogen $\left(\mathrm{N}_{2}\right)$-fixing rhizobia, thus contributing to natural $\mathrm{N}$ soil enrichment and reduced need for chemical fertilization. These crops are also a key protein resource for human and animal foods.

In legume plant roots, the interaction with rhizobia leads to the development of the nodule organ, where the nitrogenase enzyme reduces atmospheric $\mathrm{N}_{2}$ to $\mathrm{NH}_{3}$ which is afterward transferred to and assimilated by the plant. In parallel, the plant provides steady carbon source to the symbiont and a suitable microenvironment for development (Markmann and Parniske, 2009). 
When selecting stress-tolerant legume crops, the impact of soil flooding and waterlogging on $\mathrm{N}_{2}$ fixation and legume productivity need to be considered. This is particularly important in areas where forage and grain legumes are cultivated on wetlands or temporarily flooded areas. Legume species differ markedly in adaptation to flood-prone areas (Striker and Colmer, 2017). Tolerant legume species are generally able to sustain the oxygen $\left(\mathrm{O}_{2}\right)$ diffusion path under waterlogging via physiological adaptation. An increased aerenchyma network in the root and nodule cortex, the presence of a barrier to radial $\mathrm{O}_{2}$ loss in the outer root tissues and an increased permeability of the nodule $\mathrm{O}_{2}$ diffusion barrier (ODB) can facilitate tolerance (Striker and Colmer, 2017). Metabolic acclimation and the presence of alternative nodulation strategies are additional adaptation responses to waterlogging (Roberts et al., 2010).

The aim of this mini review is to explore the mechanisms underlying legume plant adaptation, symbiosis development and nodule functioning under waterlogging.

\section{WATERLOGGING EFFECTS ON PLANT-BACTERIA INTERACTION}

\section{Effects of Hypoxia on Nodulation}

Successful symbiosis involves an initial cross-talk between plants and bacteria, with the coordinated expression of genes from both partners to induce molecular re-programming, which leads to the development of a nodule (Oldroyd and Downie, 2008). Bacteria sense the plant-derived flavonoids of the root exudates and produce nodulation factors (named Nod factors), lipochito-oligosaccharide molecules that participate in bacterial infection and, when perceived by the plant, trigger the nodule's specific developmental program (Dénarié and Cullimore, 1993).

Several studies have considered the waterlogging effect on nodulation capacity. Hypoxia-sensitive legumes, such as pea (Minchin and Pate, 1975), alfalfa (Arrese-Igor et al., 1993), and soybean (Sung, 1993) exhibit reduced nodule weight when grown under hypoxic conditions. Medicago truncatula nodulation shows a $45 \%$ decrease under $0.1 \% \mathrm{O}_{2}$ but is not affected by $4.5 \% \mathrm{O}_{2}$ treatment, and the nodule fresh weight per plant is not dampened by 4 weeks of hypoxia (El Msehli et al., 2016). Two studies analyzing nodulation ratings of 21 species of annual pasture legumes and 13 species of perennial legumes (Nichols et al., 2008a,b) report that most legume, including waterlogging sensitive species such as Melilotus albus and Medicago sativa, showed effective nodulation after several weeks of inundation. In this context, it is unclear whether the nature of nodule types may support different mechanisms of dealing with the stress, considering that indeterminate nodules (Medicago spp., Pisum spp., and Melilotus spp.) are characterized by a persistent meristem and a continuous growth, while determinate nodules (Glycine spp, Vigna spp, and Lotus spp.) are characterized by a not persistent meristem and a limited growth potential.

In flood-tolerant legume species, the nodulation process shows some morphological and physiological adaptations. In Melilotus siculus, nodules formed during waterlogging stress have been observed above all on adventitious roots (Konnerup et al., 2018). Under flooding, Sesbania rostrata, a tropical legume that grows in temporary flooded habitats (Capoen et al., 2010), switches from a typical root hair curling (RHC) mechanism of nodulation to a lateral root based (LRB) one (D'Haeze et al., 2000; Goormachtig et al., 2004). When grown in aerated soils, S. rostrata nodulation occurs through the mechanism of RHC, where bacterial colony is entrapped in growing root hairs that start to curl. When LRB infection occurs, bacteria enter at the base of the adventitious or lateral roots where they form an infection pocket prior to bacteria release into the nodule primordium.

Interestingly, $S$. rostrata LRB nodulation requires ethylene (Goormachtig et al., 2004), whose production is stimulated in plants by flooding and accumulates under water due to a slow diffusion. Ethylene inhibitors blocks S. rostrata initiation of nodulation, since bacterial invasion, infection pocket formation and nodule primordia were not observed in hydroponic roots (D'Haeze et al., 2003). Moreover, ethylene is likely involved together with ROS in inducing the programmed cell death of cortical cells, which is necessary for the formation of the infection pocket occurring during crack invasion (D'Haeze et al., 2003).

On the other hand, ethylene accumulation inhibits the RHC invasion of S. rostrata (Goormachtig et al., 2004). The application of ethylene biosynthesis inhibitors resulted in an increased RHC nodulation, while the opposite was observed adding ethylene precursors (Goormachtig et al., 2004). Indeed, ethylene inhibits nodulation in several legumes, such as M. truncatula (Penmetsa and Cook, 1997) and Pisum sativum (Guinel and Sloetjes, 2000).

\section{Effects of Oxygen Availability on Nodule Functioning}

Once inside the forming nodule, bacteria differentiate into bacteroids, which can fix $\mathrm{N}_{2}$ via the activity of nitrogenase enzyme, representing the fundamental reaction of the symbiosis (Roberts et al., 2010). Nitrogenase is inactivated by free $\mathrm{O}_{2}$, thus $\mathrm{N}_{2}$ fixation is made possible thanks to the microoxic conditions predominant in the nodules. Furthermore, bacterial genes for nitrogenase assembly are expressed at low $\mathrm{O}_{2}$ concentration (Soupène et al., 1995). Nodules have evolved adaptations to maintain an inner low $\mathrm{O}_{2}$ environment, among which the presence of the ODB and by expressing $\mathrm{O}_{2}$-carrying symbiotic plant hemoglobins (Appleby, 1992; Berger et al., 2018). Thus, the developing nodule shifts from a normoxic state during the formation of the symbiosis to a microoxic one in mature nodules (Witty and Minchin, 1990). As a consequence, nodules are naturally microoxic organs that maintain a low $\mathrm{O}_{2}$ level, while preserving an active energy production.

The presence of a flexible ODB that regulates the $\mathrm{O}_{2}$ influx into the infected zone of the nodule was questioned over years. The ODB is likely composed by cortical boundary layers, matrix glycoproteins and endodermis modifications, which depend on the nature of the legume-rhizobia association (Minchin et al., 2008). Early studies on nodule structure identified the absence of a physical barrier in the soybean nodules cortex and the presence of continuous air pathways (Bergersen and Goodchild, 1972; Sprent, 1972). Subsequently, studies on pea and lupine nodules 
identified few intercellular spaces in the cortical cell layers and the absence of intercellular space connections within the nodule infected areas (Dixon et al., 1981). Indeed, occlusion in intercellular spaces were observed in the inner cortex of soybean nodule exposed to high $\mathrm{O}_{2}$ level, suggesting the presence of a flexible mechanism of morphological and structural adaptation (Serraj et al., 1995).

As underground organs, nodules can be exposed to flooding. The adaptation of functioning nodules to waterlogging includes structural and metabolic changes. Several adaptive processes have been described in nodules, including the tight regulation of the ODB flexibility, the development of aerenchyma and the setup of a specific ATP regenerating metabolism under low $\mathrm{O}_{2}$ level. Hypoxia-tolerant Lotus uliginosus nodules under flooding showed a lower concentration of matrix glycoproteins within intercellular spaces of the cortex in comparison with the sensitive species L. corniculatus (James and Crawford, 1998). This suggests a hypoxia-dependent mechanism capable to decrease the occlusions under low $\mathrm{O}_{2}$ availability and finalized to open air pathways when necessary. Recently, nodules of $M$. truncatula exposed to high $\mathrm{O}_{2}$ concentration showed a tightening of the ODB (Avenhaus et al., 2016). As consequence, the modulation of the $\mathrm{O}_{2}$ supply to the infected zone may be a key factor of nodule activity regulation. Under high $\mathrm{O}_{2}$ concentration, after a transient nitrogenase inhibition, the recovery of nitrogenase was observed and attributed to flexible ODB (Hunt et al., 1989; del Castillo et al., 1992; Avenhaus et al., 2016).

A crucial trait for plant survival under waterlogging is the possibility to develop aerenchyma, in order to provide a path for $\mathrm{O}_{2}$ diffusion along the roots from the aerated organs above (Colmer and Voesenek, 2009). The fact that some forage legumes are sensitive to waterlogging has been attributed to the limited possibility of $\mathrm{O}_{2}$ flux through aerenchyma to the root nodules (Arrese-Igor et al., 1993; Pugh et al., 1995; Konnerup et al., 2018). Some tolerant legumes have developed an extensive network of aerenchyma tissues, as indicated by the tolerant species phenotype identified in Table $\mathbf{1}$.

Given that $\mathrm{N}_{2}$ fixation is sensitive to low $\mathrm{O}_{2}$ condition occurring under flooding, soybean nodules have shown an impaired $\mathrm{N}_{2}$ fixation activity when transferred to a hydroponic solution (Justino and Sodek, 2013; Souza et al., 2016). Under these conditions, a change in $\mathrm{N}$ metabolism (Souza et al., 2016) and in the export of $\mathrm{N}_{2}$ fixation products in the xylem have been observed (Amarante and Sodek, 2006). In soybean nodules under flooding, a reduction in asparagine an accumulation of $\gamma$-aminobutyric acid (GABA) has been detected, which have been suggested to have a temporary storage role (Souza et al., 2016). These changes were reversible during recovery. Under hypoxia, the activation of the alanine metabolism was observed in waterlogging tolerant L. japonicus root and nodules, independently of the $\mathrm{N}$ status of the plant (Rocha et al., 2010b). Alanine accumulation was also observed in soybean roots under waterlogging (Rocha et al., 2010a). Alanine metabolism may be crucial to prevent pyruvate accumulation in order to facilitate glycolysis during waterlogging (Rocha et al., 2010b).

A further adaptive mechanism is related to the presence of hemoglobin-like proteins in the nodules, recently renamed phytoglobins (Hill et al., 2016). Three types of phytoglobins (phytoglobin1, leghemoglobin, and phytoglobin3) have been characterized in legume nodules (Bustos-Sanmamed et al., 2011; Berger et al., 2018). They are known to buffer $\mathrm{O}_{2}$ concentration and to scavenge nitric oxide (NO). Hypoxia generates $\mathrm{NO}$ in plants, likely with the presence of a cyclic respiration that improves the plant's capacity to tolerate hypoxic stress by maintaining the cell energy status (Igamberdiev and Hill, 2009; Gupta and Igamberdiev, 2011). This phytoglobin-NO respiration (PNR) involves the following phases: nitrate to nitrite reduction via the activity of nitrate reductase; nitrite translocation from the cytosol into the mitochondria; production of NO through the reduction of nitrite at both the cytochrome $\mathrm{C}$ oxidase and the alternative oxidase sites of the mitochondrial electron transport chain, which allows ATP regeneration; NO movement from the mitochondrial matrix to the cytosol; and NO oxidation to nitrate by phytoglobins.

Interestingly, functional nodules of $M$. truncatula (Baudouin et al., 2006), Glycine max (Meakin et al., 2007), and L. japonicus (Shimoda et al., 2009), have been shown to produce NO, and flooding conditions significantly increases NO production in soybean (Meakin et al., 2007; Sánchez et al., 2010), and M. truncatula hypoxic nodules (Horchani et al., 2011). In $M$. truncatula nodules, energy status appears to be dependent on the PNR cycle partly under normoxia and totally under hypoxia (Horchani et al., 2011). Thus, the functioning of PNR in microoxic nodules enables the plant to oxidize $\mathrm{NADH}$ and to sustain ATP synthesis also under $\mathrm{O}_{2}$ shortage.

\section{OXYGEN SIGNALING IN PLANT AND BACTERIAL PARTNERS}

\section{Oxygen Sensing in the Plant Partner}

The Ethylene Responsive Factor group VII family (ERF-VII) guides the response to $\mathrm{O}_{2}$ level variations to ensure plant survival (Gibbs et al., 2011; Licausi et al., 2011). In Arabidopsis, this family is composed of five transcription factors which all possess an $\mathrm{N}$-terminal amino acid (N-degron) and Cys residue in the second position of the protein. ERF-VII proteins are degraded via the $\mathrm{N}$-end rule-dependent proteasome pathway triggered by Plant Cysteine Oxidases (PCOs) in an $\mathrm{O}_{2}$-dependent manner (Weits et al., 2014; White et al., 2017; Figure 1A).

Together with $\mathrm{O}_{2}$, NO destabilizes ERF-VIIs, and a reduction in the availability of either gasses is sufficient to stabilize them (Gibbs et al., 2014). The discovery of this $\mathrm{O}_{2} / \mathrm{NO}$ sensing mechanism has opened up new possibilities for better understanding the plant adaptation to low $\mathrm{O}_{2}$ and for improving flooding tolerance in crops.

An interesting link has been found between Arabidopsis ERFVIIs and microorganisms. Infection by the obligate biotroph Plasmodiophora brassicae, which causes clubroot development (Gravot et al., 2016), was found to involve ERF-VIIs control. Subsequent to the identification of fermentation-related genes induced in infected root galls, the authors suggested that $\mathrm{N}$-end rule-driven hypoxia responses are a general trait of pathogeninduced gall growth (Gravot et al., 2016). In the context of 
TABLE 1 | Waterlogging tolerant and sensitive legumes.

\begin{tabular}{|c|c|c|c|}
\hline Species & Treatment & Phenotype & References \\
\hline Cicer arietinum, Vicia faba (sensitive) & $\begin{array}{l}\text { Deoxygenated stagnant solution } \\
\text { (7 days) }\end{array}$ & Death of root tips & Munir et al., 2019 \\
\hline Melilotus siculus accessions (tolerant) & $\begin{array}{l}\text { Deoxygenated stagnant solution } \\
\text { (7 days) }\end{array}$ & Root phellem abundance & Striker et al., 2019 \\
\hline $\begin{array}{l}\text { Lotus tenuis, L. tenuis } \times \text { L. corniculatus } \\
\text { (tolerant) }\end{array}$ & Partial submergence stress (55 days) & $\begin{array}{l}\text { Aerenchyma and adventitious root } \\
\text { formation }\end{array}$ & Antonelli et al., 2018 \\
\hline Melilotus siculus (tolerant) & Waterlogging (21 days) & $\begin{array}{l}\text { Aerenchymatous phellem in hypocotyl, } \\
\text { roots and the outer tissue layers of } \\
\text { nodules }\end{array}$ & Konnerup et al., 2018 \\
\hline Pisum sativum (tolerant accessions) & Waterlogging (4, 8 days) & Successful germination & Zaman et al., 2018 \\
\hline $\begin{array}{l}\text { Phaseolus vulgaris (sensitive and } \\
\text { tolerant accessions) }\end{array}$ & Flooding conditions (1, 10 days) & $\begin{array}{l}\text { Root weight and germination rate traits } \\
\text { associated to flooding tolerance }\end{array}$ & Soltani et al., 2017 \\
\hline $\begin{array}{l}\text { Lens culinaris (sensitive and tolerant } \\
\text { genotypes) }\end{array}$ & Waterlogging (6 days) & Successful germination & Wiraguna et al., 2017 \\
\hline $\begin{array}{l}\text { Vicia faba (tolerant), Pisum sativum } \\
\text { (sensitive), Lupinus albus (sensitive) }\end{array}$ & $\begin{array}{l}\text { Waterlogging at flowering }(0,5,10,15 \text {, } \\
20 \text { days })\end{array}$ & $\begin{array}{l}\text { Better seed yield and biomass of } \\
\text { shoots, roots and nodules in tolerant } \\
\text { genotypes }\end{array}$ & Pampana et al., 2016 \\
\hline Phaseolus coccineus (tolerant) & Flooding (24, 48 hours) & Vascular cavity formation & Takahashi et al., 2016 \\
\hline $\begin{array}{l}\text { Pisum sativum, Lens culinaris and } \\
\text { Lathyrus sativus (sensitive and tolerant } \\
\text { genotypes) }\end{array}$ & Waterlogging (14 days) & $\begin{array}{l}\text { High root porosity and unaffected shoot } \\
\text { nitrogen content in tolerant genotypes }\end{array}$ & Malik et al., 2015 \\
\hline Melilotus siculus accessions (tolerant) & Hypoxic saline condition (21 days) & Plant ability to regulate ions & Striker et al., 2015 \\
\hline Aeschynomene americana (tolerant) & Waterlogging (30-40 days) & High nitrogenase activity and growth & Tobisa et al., 2014 \\
\hline $\begin{array}{l}\text { Lotus japonicus recombinant inbred } \\
\text { lines (tolerant) }\end{array}$ & Waterlogging (21 days) & $\begin{array}{l}\text { Aerenchyma formation and high } \\
\text { stomatal conductance }\end{array}$ & Striker et al., 2014 \\
\hline $\begin{array}{l}\text { Melilotus siculus (tolerant accessions), } \\
\text { Trifolium michelianum (sensitive), and } \\
\text { Medicago polymorpha (sensitive) }\end{array}$ & $\begin{array}{l}\text { Waterlogging combined to salinity } \\
\text { ( } 5 \text { days) }\end{array}$ & High root porosity in tolerant genotypes & Teakle et al., 2012 \\
\hline Melilotus siculus (tolerant) & Stagnant solution (21 days) & Aerenchymatous phellem development & Teakle et al., 2011 \\
\hline Lotus tenuis (tolerant) & Waterlogging (30 days) & Shoot elongation & Manzur et al., 2009 \\
\hline $\begin{array}{l}\text { Vigna radiata (tolerant and sensitive } \\
\text { genotypes) }\end{array}$ & Waterlogging (4, 8 days) & $\begin{array}{l}\text { Availability of root sugar reserves in } \\
\text { tolerant genotypes }\end{array}$ & Sairam et al., 2009 \\
\hline $\begin{array}{l}\text { Lotus spp (tolerant and sensitive } \\
\text { genotypes) }\end{array}$ & Waterlogging (19 weeks) & $\begin{array}{l}\text { Aerenchyma and adventitious roots } \\
\text { formation in tolerant genotypes }\end{array}$ & Real et al., 2008 \\
\hline $\begin{array}{l}\text { Faba bean, yellow lupin, grass pea, } \\
\text { narrow-leafed lupin, chickpea, lentil, } \\
\text { field pea (tolerant and sensitive } \\
\text { genotypes) }\end{array}$ & Waterlogging (7 days) & $\begin{array}{l}\text { Adventitious root and aerenchyma } \\
\text { formation in tolerant genotypes }\end{array}$ & Solaiman et al., 2007 \\
\hline $\begin{array}{l}\text { Lupinus luteus (tolerant), } \\
\text { L. angustifolius (sensitive) reciprocal- } \\
\text { and self-grafted combinations }\end{array}$ & Waterlogging (14 days) & $\begin{array}{l}\text { Tolerance influenced by the root } \\
\text { genotype }\end{array}$ & Davies et al., 2000 \\
\hline $\begin{array}{l}\text { Trifolium tomentosum (tolerant) and } \\
\text { T. glomeratum (sensitive) }\end{array}$ & Hypoxic solution (7-21 days) & $\begin{array}{l}\text { High root porosity in the tolerant } \\
\text { genotype }\end{array}$ & Gibberd et al., 1999 \\
\hline
\end{tabular}

pathogenesis, the resistance to the hemibiotrophic pathogen, Pseudomonas syringae pv tomato has been shown to involve ERFVIIs substrates to regulate pathogen-induced stomatal closure in Arabidopsis (Vicente et al., 2018).

To date, no data are available on the ERF-VIIs role in $\mathrm{N}_{2}$-fixing symbioses in legumes. In fact, the genome of $M$. truncatula (version Mt4. $0^{1}$ ) harbors four genes that belong to the ERF-VIIs group (Boscari et al. (2013), personal communication), and phylogenetic analysis revealed the presence of ERF-VIIs in the G. max genome (Licausi et al., 2011). These ERF-VIIs harbor the conserved N-terminal degron, which suggests their control

\footnotetext{
${ }^{1}$ http://www.medicagogenome.org/home
}

by $\mathrm{O}_{2}$ levels. A previous RNA-Seq analysis of $M$. truncatula during the symbiotic interaction with Sinorhizobium meliloti showed that ERF-VII genes are expressed in both roots and nodules (Boscari et al., 2013), where they may be crucial under microoxic conditions. ERF-VIIs might be an excellent candidate for deciphering $\mathrm{O}_{2}$ perception and $\mathrm{NO}$ signaling in $\mathrm{N}_{2}$-fixing symbioses. Indeed, interesting aspects are related to the possible targets of ERF-VIIs in nodule, which may be involved in morphological and metabolic adaptations in the microoxic nodule niche and under environmental hypoxia. In particular, speculation can be done on the possible role of ERF-VIIs on the metabolic modification in order to supply ATP under $\mathrm{O}_{2}$ scarcity and on the regulation of the ODB flexibility to different $\mathrm{O}_{2}$ 


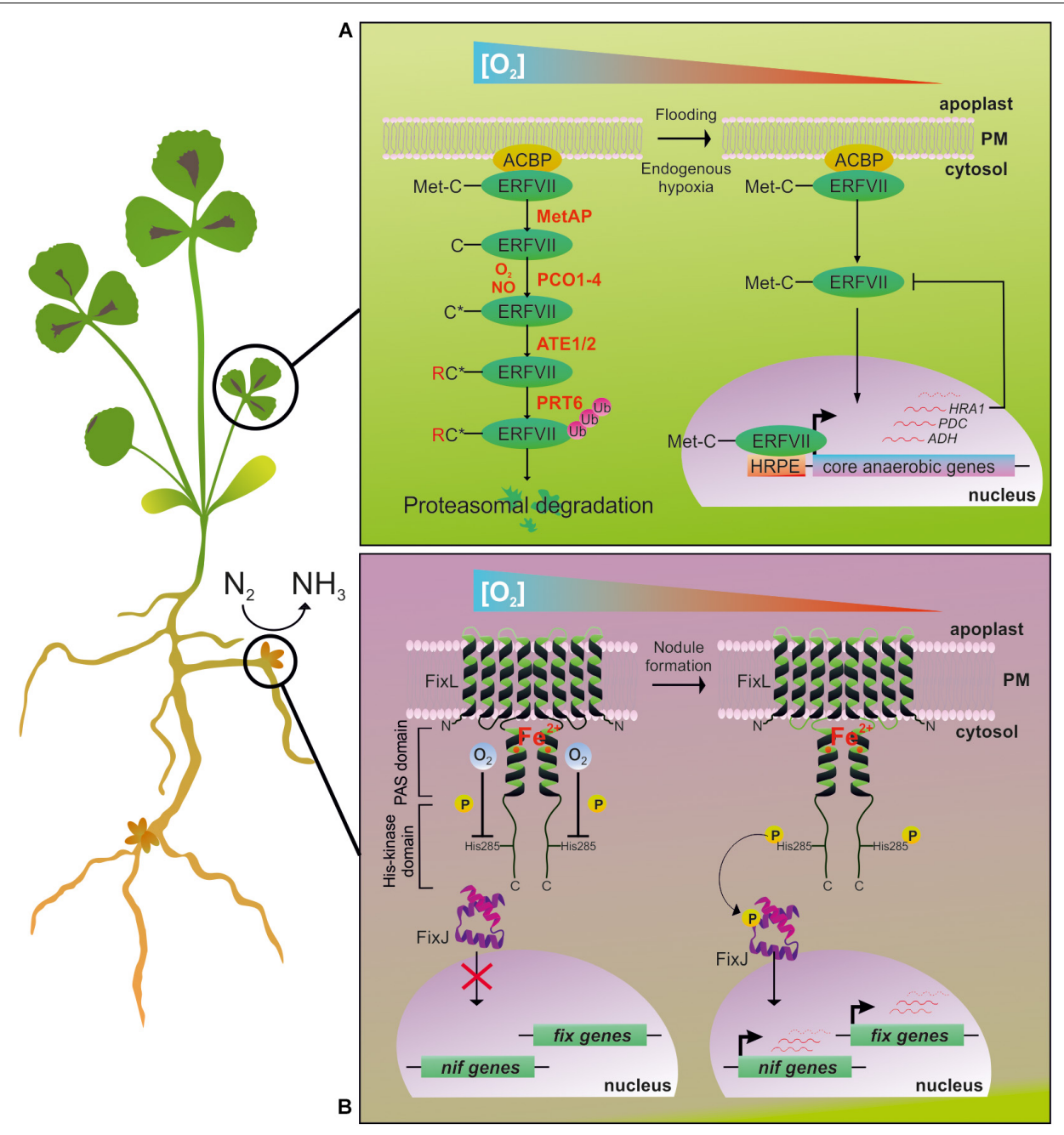

FIGURE 1 | The main $\mathrm{O}_{2}$-sensing pathways described in plants (identified in Arabidopsis and hypothesized to be present in M. truncatula) and S. meliloti $\mathrm{N}_{2}$-fixing bacteria. (A) In Arabidopsis, the Cys branch of the $\mathrm{N}$-end rule pathway for protein degradation allows the $\mathrm{O}_{2}$-dependent regulation of gene expression (Licausi et al. 2013). ERF-VIls are a class of transcription factors characterized by a conserved $\mathrm{N}$-termini ( $\mathrm{N}$-degron) in which Cys 2 determines the protein's fate in response to $\mathrm{O}_{2}$ level inside the cell. In aerobic conditions (left), ERF-VIlls are unable to activate the transcription of anaerobic genes. In these conditions, Met Aminopeptidase (MetAP) removes the N-terminal Met, and PCOs oxidize the resulting exposed Cys (C*) (Weits et al., 2014; White et al., 2017). After arginylation by Arginyl Transferases (ATE1-2), an Ubiquitin Ligase (PRT6) identifies the proteins as a degradation substrate for the $26 \mathrm{~S}$ proteasome. Under $\mathrm{O}_{2}$ deficient conditions (right), the efficiency of ERF-VIls oxidation is dampened, allowing the stabilization and translocation into the nucleus to finally induce a set of anaerobic genes (Kosmacz et al., 2015), with Arabidopsis RAP2.2 and RAP2.12 playing a major role in comparison to the other ERF-VIls (Bui et al., 2015). This also happens through fine regulation controlled by the Hypoxia Response Attenuator (HRA1), which antagonizes RAP2.12 through a feedback mechanism that enables a flexible response to different levels of $\mathrm{O}_{2}$ availability (Giuntoli et al., 2014, 2017). The cis-regulatory element Hypoxia Responsive Promoter Element (HRPE) has been identified as being enriched in some hypoxia-responsive genes (Gasch et al., 2016). (B) FixL-FixJ two-component regulatory system in S. meliloti symbiotic bacteria regulates the expression of nif and fix gene clusters in an $\mathrm{O}_{2}$-dependent way. In free-living bacteria (left), FixL is inhibited by the binding of $\mathrm{O}_{2}$ to the heme moiety inside the PAS domain. By establishing symbiosis with the plant, nodule formation gives rise to a microoxic environment surrounding the microbial cells (right). In turn, FixL is activated by auto-phosphorylation and transfers the phosphoryl group to the FixJ transcriptional activator, thus regulating nif and fix genes expression.

level. Furthermore, it would be of interest to understand whether ERF-VIIs nodule targets may be involved in plant interaction with bacteria during the infection and the $\mathrm{N}$ fixation process.

\section{The FixL-FixJ Bacterial Two Component System}

In $\mathrm{N}_{2}$-fixing rhizobia, the nitrogenase expression needs to be tightly regulated in response to changing $\mathrm{O}_{2}$ concentrations, due to the fact that $\mathrm{O}_{2}$ irreversibly inhibits the enzyme activity (Poole and Hill, 1997). The fine-tuning of nitrogenase related genes expression and the compartmentalization of the enzyme inside the nodule are thus prerequisites for an efficient $\mathrm{N}_{2}$ fixation (Soupène et al., 1995).

The induction of the $\mathrm{N}_{2}$-fixing gene cluster in $S$. meliloti and other symbiotic bacteria is regulated by a two-component system composed of the $\mathrm{O}_{2}$-sensing histidine kinase FixL and the response transcriptional regulator FixJ (Figure 1B; 
De Philip et al., 1990; Bobik et al., 2006). In S. meliloti, FixL is a protein composed of four transmembrane helices and a cytoplasmic region comprising a heme-containing Per Arnt Sim (PAS) domain and a C-terminal histidine kinase domain (Monson et al., 1992). The $\mathrm{O}_{2}$ sensing relies on the PAS domain (Gilles-Gonzalez, 2001), which is a widespread sequence found in bacterial (Green and Paget, 2004), animal (Adaixo et al., 2013), and plant (Christie et al., 2002) proteins. Oxygen exerts a negative regulation on FixL through interaction with the PAS domain.

The formation of a microoxic environment hampers the inhibitions that $\mathrm{O}_{2}$ exerts on FixL, and activates the reversible autophosphorylation of a His residue in the FixL kinase domain. Phosphorylated FixL transfers the phosphoryl group to the signal transducer, FixJ, whose phosphorylation status induces the transcription of the nif and fix gene clusters involved in nitrogen fixation and respiration (Reyrat et al., 1993; Bobik et al., 2006), via the activation of two intermediary regulatory genes, nifA and fixK. Interestingly, in S. meliloti, Meilhoc et al. (2010) identified about 100 genes up-regulated by NO, among which $70 \%$ have been described to be induced by microoxia (Bobik et al., 2006) and regulated through the FixL-FixJ system. NO present in nodules could serve as a signal to activate the FixL-FixJ system (Meilhoc et al., 2010).

\section{CONCLUDING REMARKS}

The study of symbiotic models in response to waterlogging can help in deciphering the mechanism that may be crucial for the isolation of tolerant legume crop species and varieties in the field. The steps in signal exchange for the mutual recognition, nodule

\section{REFERENCES}

Adaixo, R., Harley, C. A., Castro-Rodrigues, A. F., and Morais-Cabral, J. H. (2013). Structural properties of PAS domains from the KCNH potassium channels. PLoS One 8:e59265. doi: 10.1371/journal.pone.0059265

Amarante, L., and Sodek, L. (2006). Waterlogging effect on xylem sap glutamine of nodulated soybean. Biol. Plant. 50, 405-410. doi: 10.1007/s10535-0060057-6

Antonelli, C. J., Calzadilla, P. I., Vilas, J. M., Campestre, M. P., Escaray, F. J., and Ruiz, O. A. (2018). Physiological and anatomical traits associated with tolerance to long-term partial submergence stress in the Lotus genus: responses of forage species, a model and an interspecific hybrid. J. Agron. Crop Sci. 205, 65-76. doi: $10.1111 /$ jac. 12303

Appleby, C. A. (1992). The origin and functions of haemoglobin in plants. Sci. Prog. 76, 365-398. doi: 10.2307/43421309

Arrese-Igor, C., Royuela, M., de Lorenzo, C., de Felipe, M. R., and AparicioTejo, P. M. (1993). Effect of low rhizosphere oxygen on growth, nitrogen fixation and nodule morphology in lucerne. Physiol. Plant. 89, 55-63. doi: 10.1111/j.1399-3054.1993.tb01786.x

Avenhaus, U., Cabeza, R. A., Liese, R., Lingner, A., Dittert, K., Salinas-Riester, G., et al. (2016). Short-term molecular acclimation processes of legume nodules to increased external oxygen concentration. Front. Plant Sci. 6:1133. doi: 10.3389/ fpls.2015.01133

Baudouin, E., Pieuchot, L., Engler, G., Pauly, N., and Puppo, A. (2006). Nitric oxide is formed in Medicago truncatula-Sinorhizobium meliloti functional nodules. Mol. Plant Microbe Interact. 19, 970-975. doi: 10.1094/MPMI-19-0970 organogenesis and efficient $\mathrm{N}_{2}$ fixation under waterlogging are crucial aspects of the symbiosis. It would thus be of interest to decipher whether the sensing of $\mathrm{O}_{2}$ shortage in plant can (i) modify the perception of the partner during the symbiotic establishment, (ii) influence the nodule development, and (iii) affect the functioning of the nitrogenase enzyme in the bacteroid. These aspects may be further influenced by the high level of NO encountered in the nodule organ, which is involved, together with $\mathrm{O}_{2}$, in ERF-VIIs degradation. At the same time, the PNR cycle may offer an alternative way to produce energy under $\mathrm{O}_{2}$ shortage. A detailed analysis of these steps would help in finding interesting solutions for marginal land cultivation with waterlogging tolerant legumes capable of fixing $\mathrm{N}_{2}$ where limited $\mathrm{O}_{2}$ is available.

\section{AUTHOR CONTRIBUTIONS}

$\mathrm{CP}$ and $\mathrm{AB}$ conceived the idea of the review. All the authors were involved in the manuscript writing.

\section{FUNDING}

We would like to thank Campus France and the Franco Italian University for funding and supporting the scientific exchange under the Partnership Hubert Curien (PHC) Galilee Project 34602QF, G15-11. CP, AT, and PP acknowledge funding by Scuola Superiore Sant'Anna. AB and RB are supported by the French Institut National de la Recherche Agronomique (INRA) and by the Partnership Hubert Curien (PHC) Utique Project 17G0904.

Berger, A., Brouquisse, R., Pathak, P. K., Hichri, I., Singh, I., Bhatia, S., et al. (2018). Pathways of nitric oxide metabolism and operation of phytoglobins in legume nodules: missing links and future directions. Plant. Cell Environ. 41, 2057-2068. doi: $10.1111 /$ pce. 13151

Bergersen, F. J., and Goodchild, D. J. (1972). Aeration pathways in soybean root nodules. Aust. J. Biol. Sci. 26, 729-740. doi: 10.1071/BI9730729

Bobik, C., Meilhoc, E., and Batut, J. (2006). FixJ: a major regulator of the oxygen limitation response and late symbiotic functions of Sinorhizobium meliloti. J. Bacteriol. 188, 4890-4902.

Boscari, A., Del Giudice, J., Ferrarini, A., Venturini, L., Zaffini, A. L., Delledonne, M., et al. (2013). Expression dynamics of the Medicago truncatula transcriptome during the symbiotic interaction with Sinorhizobium meliloti: which role for nitric oxide? Plant Physiol. 161, 425-439. doi: 10.1104/pp.112.208538

Bui, L. T., Giuntoli, B., Kosmacz, M., Parlanti, S., and Licausi, F. (2015). Constitutively expressed ERF-VII transcription factors redundantly activate the core anaerobic response in Arabidopsis thaliana. Plant Sci. 236, 37-43. doi: $10.1016 /$ j.plantsci.2015.03.008

Bustos-Sanmamed, P., Tovar-Méndez, A., Crespi, M., Sato, S., Tabata, S., and Becana, M. (2011). Regulation of nonsymbiotic and truncated hemoglobin genes of Lotus japonicus in plant organs and in response to nitric oxide and hormones. New Phytol. 189, 765-776. doi: 10.1111/j.1469-8137.2010. 03527.x

Capoen, W., Goormachtig, S., and Holsters, M. (2010). Water-tolerant legume nodulation. J. Exp. Bot. 61, 1251-1255. doi: 10.1093/jxb/erp326

Christie, J. M., Swartz, T. E., Bogomolni, R. A., and Briggs, W. R. (2002). Phototropin LOV domains exhibit distinct roles in regulating 
photoreceptor function. Plant J. 32, 205-219. doi: 10.1046/j.1365-313X.2002. 01415.x

Colmer, T. D., and Voesenek, L. A. C. J. (2009). Flooding tolerance: suites of plant traits in variable environments. Funct. Plant Biol. 36, 665-681. doi: 10.1071/ FP09144

Davies, C. L., Turner, D. W., and Dracup, M. (2000). Yellow lupin (Lupinus luteus) tolerates waterlogging better than narrow-leafed lupin (L. angustifolius): II. Leaf gas exchange, plant water status, and nitrogen accumulation. Aust. J. Agric. Res. 51, 711-719. doi: 10.1071/AR99074

De Philip, P., Batut, J., and Boistard, P. (1990). Rhizobium meliloti FixL is an oxygen sensor and regulates $R$. meliloti nifA and fixK genes differently in Escherichia coli. J. Bacteriol. 172, 4255-4262. doi: 10.1128/jb.172.8.4255-4262. 1990

del Castillo, L. D. D., Hunt, S., and Layzell, D. B. (1992). O2 regulation and O2limitation of nitrogenase activity in root nodules of pea and lupin. Physiol. Plant. 86, 269-278. doi: 10.1034/j.1399-3054.1992.860212.x

Dénarié, J., and Cullimore, J. (1993). Lipo-oligosaccharide nodulation factors: a new class of signaling molecules mediating recognition and morphogenesis. Cell 74, 951-954. doi: 10.1016/0092-8674(93)90717-5

D’Haeze, W., De Rycke, R., Mathis, R., Goormachtig, S., Pagnotta, S., Verplancke, C., et al. (2003). Reactive oxygen species and ethylene play a positive role in lateral root base nodulation of a semiaquatic legume. Proc. Natl. Acad. Sci. U.S.A. 100, 11789-11794. doi: 10.1073/pnas.1333899100

D’Haeze, W., Mergaert, P., Promé, J. C., and Holsters, M. (2000). Nod factor requirements for efficient stem and root nodulation of the tropical legume Sesbania rostrata. J. Biol. Chem. 275, 15676-15684. doi: 10.1074/jbc.275.21. 15676

Dixon, R. O. D., Blunden, E. A. G., and Searl, J. W. (1981). Intercellular space and hydrogen diffusion in pea and lupin root nodules. Plant Sci. Lett. 23, 109-116.

El Msehli, S., Rima, N., Sghaier, H., Aschi-Smiti, S., and Brouquisse, R. (2016). Impact of hypoxia on nodulation and growth of the legume plant Medicago truncatula in symbiosis with Sinorhizobium meliloti. Int. J. Curr. Res. Biosci. Plant Biol. 3, 53-60.

Erisman, J. W., Sutton, M. A., Galloway, J., Klimont, Z., and Winiwarter, W. (2008). How a century of ammonia synthesis changed the world. Nat. Geosci. 1:636. doi: 10.1038/ngeo325

Gasch, P., Fundinger, M., Müller, J., Lee, T., Bailey-Serres, J., and Mustroph, A. (2016). Redundant ERF-VII transcription factors bind to an evolutionarily conserved cis-motif to regulate hypoxia-responsive gene expression in Arabidopsis. Plant Cell 28, 160-180. doi: 10.1105/tpc.15.00866

Gerland, P., Raftery, A. E., Ševčíková, H., Li, N., Gu, D., and Spoorenberg, T. (2014). World population stabilization unlikely this century. Science 346, 234-237. doi: 10.1126/science. 1257469

Gibberd, M. R., Colmer, T. D., and Cocks, P. S. (1999). Root porosity and oxygen movement in waterlogging-tolerant Trifolium tomentosum and -intolerant Trifolium glomeratum. Plant Cell Environ. 22, 1161-1168. doi: 10.1046/j. 1365-3040.1999.00472.x

Gibbs, D. J., Lee, S. C., Md Isa, N., Gramuglia, S., Fukao, T., Bassel, G. W., et al. (2011). Homeostatic response to hypoxia is regulated by the $\mathrm{N}$-end rule pathway in plants. Nature 479, 415-418. doi: 10.1038/nature10534

Gibbs, D. J., Mdisa, N., Movahedi, M., Lozano-Juste, J., Mendiondo, G. M., Berckhan, S., et al. (2014). Nitric oxide sensing in plants is mediated by proteolytic control of group VII ERF transcription factors. Mol. Cell. 53, 369-379. doi: 10.1016/j.molcel.2013.12.020

Gilles-Gonzalez, M. A. (2001). Oxygen signal transduction. IUBMB Life 51, 165-173. doi: 10.1080/152165401753544232

Giuntoli, B., Lee, S. C., Licausi, F., Kosmacz, M., Oosumi, T., van Dongen, J. T., et al. (2014). A trihelix DNA binding protein counterbalances hypoxia-responsive transcriptional activation in Arabidopsis. PLoS Biol. 12:e1001950. doi: 10.1371/ journal.pbio. 1001950

Giuntoli, B., Licausi, F., van Veen, H., and Perata, P. (2017). Functional balancing of the hypoxia regulators RAP2.12 and HRA1 takes place in vivo in Arabidopsis thaliana plants. Front. Plant Sci. 8:591. doi: 10.3389/fpls.2017.00591

Goormachtig, S., Capoen, W., and Holsters, M. (2004). Rhizobium infection: lessons from the versatile nodulation behaviour of water-tolerant legumes. Trends Plant Sci. 9, 518-522. doi: 10.1016/j.tplants.2004.09.005

Gravot, A., Richard, G., Lime, T., Lemarié, S., Jubault, M., Lariagon, C., et al. (2016). Hypoxia response in Arabidopsis roots infected by Plasmodiophora brassicae supports the development of clubroot. BMC Plant Biol. 16:251. doi: 10.1186/ s12870-016-0941-y

Green, J., and Paget, M. S. (2004). Bacterial redox sensors. Nat. Rev. Microbiol. 2, 954-966. doi: 10.1038/nrmicro1022

Guinel, F. C., and Sloetjes, L. L. (2000). Ethylene is involved in the nodulation phenotype of Pisum sativum R50 (sym 16), a pleiotropic mutant that nodulates poorly and has pale green leaves. J. Exp. Bot. 51, 885-894. doi: 10.1093/jexbot/ 51.346.885

Gupta, K. J., and Igamberdiev, A. U. (2011). The anoxic plant mitochondrion as a nitrite: NO reductase. Mitochondrion 11, 537-543. doi: 10.1016/j.mito.2011. 03.005

Hill, R., Hargrove, M., and Arredondo-Peter, R. (2016). Phytoglobin: a novel nomenclature for plant globins accepted by the globin community at the 2014 XVIII conference on oxygen-binding and sensing proteins. F1000Res. 5:212. doi: 10.12688/f1000research.8133.1

Horchani, F., Prévot, M., Boscari, A., Evangelisti, E., Meilhoc, E., Bruand, C., et al. (2011). Both plant and bacterial nitrate reductases contribute to nitric oxide production in Medicago truncatula nitrogen-fixing nodules. Plant Physiol. 155, 1023-1036. doi: 10.1104/pp.110.166140

Hunt, S., King, B. J., and Layzell, D. B. (1989). Effects of gradual increases in O2 concentration on nodule activity in soybean. Plant Physiol. 91, 315-321. doi: $10.1104 /$ pp.91.1.31

Igamberdiev, A. U., and Hill, R. D. (2009). Plant mitochondrial function during anaerobiosis. Ann. Bot. 103, 259-268. doi: 10.1093/aob/mcn100

James, E. K., and Crawford, R. M. M. (1998). Effect of oxygen availability on nitrogen fixation by two Lotus species under flooded conditions. J. Exp. Bot. 49, 599-609. doi: 10.1093/jxb/49.320.599

Justino, G. C., and Sodek, L. (2013). Recovery of nitrogen fixation after short-term flooding of the nodulated root system of soybean. J. Plant Physiol. 170, 235-241. doi: 10.1016/j.jplph.2012.10.006

Konnerup, D., Toro, G., Pedersen, O., and Colmer, T. D. (2018). Waterlogging tolerance, tissue nitrogen and oxygen transport in the forage legume Melilotus siculus: a comparison of nodulated and nitrate-fed plants. Ann. Bot. 121, 699-709. doi: 10.1093/aob/mcx202

Kosmacz, M., Parlanti, S., Schwarzländer, M., Kragler, F., Licausi, F., and Van Dongen, J. T. (2015). The stability and nuclear localization of the transcription factor RAP2.12 are dynamically regulated by oxygen concentration. Plant Cell Environ. 38, 1094-1103. doi: 10.1111/pce.12493

Licausi, F., Kosmacz, M., Weits, D. A., Giuntoli, B., Giorgi, F. M., Voesenek, L. A. C. J., et al. (2011). Oxygen sensing in plants is mediated by an N-end rule pathway for protein destabilization. Nature 479, 419-422. doi: 10.1038/ nature 10536

Licausi, F., Pucciariello, C., and Perata, P. (2013). New role for an old rule: N-end rule-mediated degradation of ethylene responsive factor proteins governs low oxygen response in plants. J. Integr. Plant Biol. 55, 31-39. doi: 10.1111/jipb. 12011

Malik, A. I., Ailewe, T. I., and Erskine, W. (2015). Tolerance of three grain legume species to transient waterlogging. AoB Plants 7:lv041. doi: 10.1093/aobpla/ plv041

Manzur, M. E., Grimoldi, A. A., Insausti, P., and Striker, G. G. (2009). Escape from water or remain quiescent? Lotus tenuis changes its strategy depending on depth of submergence. Ann. Bot. 104, 1163-1169. doi: 10.1093/aob/mcp203

Markmann, K., and Parniske, M. (2009). Evolution of root endosymbiosis with bacteria: how novel are nodules? Trends Plant Sci. 14, 77-86. doi: 10.1016/j. tplants.2008.11.009

Meakin, G. E., Bueno, E., Jepson, B., Bedmar, E. J., Richardson, D. J., and Delgado, M. J. (2007). The contribution of bacteroidal nitrate and nitrite reduction to the formation of nitrosylleghaemoglobin complexes in soybean root nodules. Microbiology 153, 411-419. doi: 10.1099/mic.0.2006/000059-0

Meilhoc, E., Cam, Y., Skapski, A., and Bruand, C. (2010). The response to nitric oxide of the nitrogen-fixing symbiont Sinorhizobium meliloti. Mol. Plant Microbe Interact. 23, 748-759. doi: 10.1094/MPMI-23-6-0748

Minchin, F. R., James, E. K., and Becana, M. (2008). “Oxygen diffusion, production of reactive oxygen and nitrogen species, and antioxidants in legume nodules," in Nitrogen-Fixing Leguminous Symbioses. Nitrogen Fixation: Origins, Applications, and Research Progress, eds M. J. Dilworth, E. K. James, J. I. Sprent, and W. E. Newton (Dordrecht: Springer), 321-362. doi: 10.1007/978-1-4020-35487_11 
Minchin, F. R., and Pate, J. S. (1975). Effects of water, aeration, and salt regime on nitrogen fixation in a nodulated legume-definition of an optimum root environment. J. Exp. Bot. 26, 60-69.doi: 10.1093/jxb /26.1.60

Monson, E. K., Weinstein, M., Ditta, G. S., and Helinski, D. R. (1992). The FixL protein of Rhizobium meliloti can be separated into a heme-binding oxygensensing domain and a functional C-terminal kinase domain. Proc. Natl. Acad. Sci. U.S.A. 89, 4280-4284. doi: 10.1073/pnas.89.10.4280

Munir, R., Konnerup, D., Khan, H. A., Siddique, K. H. M., and Colmer, T. D. (2019). Sensitivity of chickpea and faba bean to root-zone hypoxia, elevated ethylene, and carbon dioxide. Plant Cell Environ. 42, 85-97. doi: 10.1111/pce. 13173

Nichols, P. G. H., Craig, A. D., Rogers, M. E., Albertsen, T. O., Miller, S. M., McClements, D. R., et al. (2008a). Production and persistence of annual pasture legumes at five saline sites in southern Australia. Aust. J. Exp. Agric. 48, 518-535. doi: $10.1071 /$ EA07167

Nichols, P. G. H., Rogers, M. E., Craig, A. D., Albertsen, T. O., Miller, S. M., McClements, D. R., et al. (2008b). Production and persistence of temperate perennial grasses and legumes at five saline sites in southern Australia. Aust. J. Exp. Agric. 48, 536-552. doi: 10.1071/EA07168

Oldroyd, G. E. D., and Downie, J. A. (2008). Coordinating nodule morphogenesis with rhizobial infection in legumes. Annu. Rev. Plant Biol. 59, 519-546. doi: 10.1146/annurev.arplant.59.032607.092839

Pampana, S., Masoni, A., and Arduini, I. (2016). Response of cool-season grain legumes to waterlogging at flowering. Can. J. Plant Sci. 96, 597-603. doi: 10.1139/cjps-2015-0268

Penmetsa, R. V., and Cook, D. R. (1997). A legume ethylene-insensitive mutant hyperinfected by its rhizobial symbiont. Science 275, 527-530. doi: 10.1126/ science.275.5299.527

Poole, R. K., and Hill, S. (1997). Respiratory protection of nitrogenase activity in Azotobacter vinelandii-roles of the terminal oxidases. Biosci. Rep. 17, 303-317.

Pugh, R., Witty, J. F., Mytton, L. R., and Minchin, F. R. (1995). The effect of waterlogging on nitrogen fixation and nodule morphology in soil-grown white clover (Trifolium repens L.). J. Exp. Bot. 46, 285-290. doi: 10.1093/jxb/46. 3.285

Real, D., Warden, J., Sandral, G. A., and Colmer, T. D. (2008). Waterlogging tolerance and recovery of 10 Lotus species. Anim. Prod. Sci. 48, 480-487. doi: 10.1071/EA07110

Reyrat, J. M., David, M., Blonski, C., Boistard, P., and Batut, J. (1993). Oxygenregulated in vitro transcription of Rhizobium meliloti nifA and fixK genes. J. Bacteriol. 175, 6867-6872. doi: 10.1128/JB.00251-06

Roberts, D. M., Choi, W. G., and Hwang, J. H. (2010). "Strategies for adaptation to waterlogging and hypoxia in nitrogen fixing nodules of legumes," in Waterlogging Signaling and Tolerance in Plants, eds S. Mancuso and S. Shabala (Berlin: Springer), 37-59. doi: 10.1007/978-3-642-10305-6_3

Rocha, M., Licausi, F., Araujo, W. L., Nunes-Nesi, A., Sodek, L., Fernie, A. R., et al. (2010a). Glycolysis and the tricarboxylic acid cycle are linked by alanine aminotransferase during hypoxia induced by waterlogging of Lotus japonicus. Plant Physiol. 152, 1501-1513. doi: 10.1104/pp.109.150045

Rocha, M., Sodek, L., Licausi, F., Hameed, M. W., Dornelas, M. C., and Van Dongen, J. T. (2010b). Analysis of alanine aminotransferase in various organs of soybean (Glycine max) and in dependence of different nitrogen fertilisers during hypoxic stress. Amino Acids. 39, 1043-1053. doi: 10.1007/s0 0726-010-0596-1

Sairam, R. K., Dharmar, K., Chinnusamy, V., and Meena, R. C. (2009). Waterlogging-induced increase in sugar mobilization, fermentation, and related gene expression in the roots of mung bean (Vigna radiata). J. Plant Physiol. 166, 602-616. doi: 10.1016/j.jplph.2008.09.005

Sánchez, C., Gates, A. J., Meakin, G. E., Uchiumi, T., Girard, L., Richardson, D. J., et al. (2010). Production of nitric oxide and nitrosylleghemoglobin complexes in soybean nodules in response to flooding. Mol. Plant. Microbe Interact. 23, 702-711. doi: 10.1094/MPMI-23-5-0702

Serraj, R., Fleurat-Lessard, P., Jaillard, B., and Drevon, J. J. (1995). Structural changes in the inner-cortex cells of soybean root-nodules are induced by shortterm exposure to high salt or oxygen concentrations. Plant Cell Environ. 18, 455-462. doi: 10.1111/j.1365-3040.1995.tb00380.x

Shimoda, Y., Shimoda-Sasakura, F., Kucho, K., Kanamori, N., Nagata, M., Suzuki, A., et al. (2009). Overexpression of class 1 plant hemoglobin genes enhances symbiotic nitrogen fixation activity between Mesorhizobium loti and Lotus japonicus. Plant J. 57, 254-263. doi: 10.1111/j.1365-313X.2008. 03689.x

Solaiman, Z., Colmer, T. D., Loss, S. P., Thomson, B. D., and Siddique, K. H. M. (2007). Growth responses of cool-season grain legumes to transient waterlogging. Aust. J. Agric. Res. 58, 406-412. doi: 10.1071/ AR06330

Soltani, A., MafiMoghaddam, S., Walter, K., Restrepo-Montoya, D., Mamidi, S., Schroder, S., et al. (2017). Genetic architecture of flooding tolerance in the dry bean middle-american diversity panel. Front. Plant Sci. 8:1183. doi: 10.3389/ fpls.2017.01183

Soupène, E., Foussard, M., Boistard, P., Truchet, G., and Batut, J. (1995). Oxygen as a key developmental regulator of Rhizobium meliloti N2-fixation gene expression within the alfalfa root nodule. Proc. Natl. Acad. Sci. U.S.A. 92, 3759-3763.

Souza, S. C. R., Mazzafera, P., and Sodek, L. (2016). Flooding of the root system in soybean: biochemical and molecular aspects of $\mathrm{N}$ metabolism in the nodule during stress and recovery. Amino Acids 48, 1285-1295. doi: 10.1007/s0 0726-016-2179-2

Sprent, J. I. (1972). The effects of water stress on nitrogen-fixing root nodules. New Phytol. 71, 443-450. doi: 10.1111/j.1469-8137.1972. tb01944.x

Striker, G. G., Casas, C., Manzur, M. E., Ploschuk, R. A., and Casal, J. J. (2014). Phenomic networks reveal largely independent root and shoot adjustment in waterlogged plants of Lotus japonicus. Plant Cell Environ. 37, 2278-2293. doi: $10.1111 /$ pce. 12268

Striker, G. G., and Colmer, T. D. (2017). Flooding tolerance of forage legumes. J. Exp. Bot. 68, 1851-1872. doi: 10.1093/jxb/erw239

Striker, G. G., Kotula, L., and Colmer, T. D. (2019). Tolerance to partial and complete submergence in the forage legume Melilotus siculus: an evaluation of 15 accessions for petiole hyponastic response and gas-filled spaces, leaf hydrophobicity and gas films, and root phellem. Ann. Bot. 123, 1-12. doi: $10.1093 / \mathrm{aob} / \mathrm{mcy} 153$

Striker, G. G., Teakle, N. L., Colmer, T. D., and Barrett-Lennard, E. G. (2015). Growth responses of Melilotus siculus accessions to combined salinity and rootzone hypoxia are correlated with differences in tissue ion concentrations and not differences in root aeration. Environ. Exp. Bot. 109, 89-98. doi: 10.1016/j. envexpbot.2014.08.006

Sung, F. J. M. (1993). Waterlogging effect on nodule nitrogenase and leaf nitrate reductase activities in soybean. F. Crop. Res. 35, 183-189. doi: 10.1016/03784290(93)90152-D

Takahashi, M., Niki, T., Deem, K. D., and Gladish, D. K. (2016). Vascular cavity formation enhances oxygen availability during flooding in root tips of Phaseolus coccineus L. primary roots. Int. J. Plant Sci. 177, 277-286. doi: 10.1086/ 684524

Teakle, N. L., Armstrong, J., Barrett-Lennard, E. G., and Colmer, T. D. (2011). Aerenchymatous phellem in hypocotyl and roots enables $\mathrm{O} 2$ transport in Melilotus siculus. New Phytol. 190, 340-350. doi: 10.1111/j.1469-8137.2011. 03655.x

Teakle, N. L., Bowman, S., Barrett-Lennard, E. G., Real, D., and Colmer, T. D. (2012). Comparisons of annual pasture legumes in growth, ion regulation and root porosity demonstrate that Melilotus siculus has exceptional tolerance to combinations of salinity and waterlogging. Environ. Exp. Bot. 77, 175-184. doi: 10.1016/j.envexpbot.2011.11.020

Tobisa, M., Shimojo, M., and Masuda, Y. (2014). Root distribution and nitrogen fixation activity of tropical forage legume american jointvetch (Aeschynomene americana L.) Cv. glenn under waterlogging conditions. Int. J. Agron. 2014:507405. doi: 10.1155/2014/507405

Vicente, J., Mendiondo, G. M., Pauwels, J., Pastor, V., Izquierdo, Y., Naumann, C., et al. (2018). Distinct branches of the $\mathrm{N}$-end rule pathway modulate the plant immune response. New Phytol. 221, 988-1000. doi: 10.1111/nph. 15387

Weits, D. A., Giuntoli, B., Kosmacz, M., Parlanti, S., Hubberten, H. M., Riegler, H., et al. (2014). Plant cysteine oxidases control the oxygen-dependent branch of the N-end-rule pathway. Nat. Commun. 5, 1-10. doi: 10.1038/ ncomms 4425

White, M. D., Klecker, M., Hopkinson, R. J., Weits, D. A., Mueller, C., Naumann, C., et al. (2017). Plant cysteine oxidases are dioxygenases that directly enable 
arginyl transferase-catalysed arginylation of $\mathrm{N}$-end rule targets. Nat. Commun. 8:14690. doi: 10.1038/ncomms14690

Wiraguna, E., Malik, A. I., and Erskine, W. (2017). Waterlogging tolerance in lentil (Lens culinaris Medik. subsp. culinaris) germplasm associated with geographic origin. Genet. Resour. Crop Evol. 64, 579-586. doi: 10.1007/s10722-0160385-0

Witty, J. F., and Minchin, F. R. (1990). Oxygen diffusion in the legume root nodule. Nitrogen. Fixat. Achiev. Object. 2, 285-292. doi: 10.1007/978-1-46846432-0_29

Zaman, M. S., Malik, A. I., Kaur, P., and Erskine, W. (2018). Waterlogging tolerance of pea at germination. J. Agron. Crop Sci. 204, 155-164. doi: 10.1111/jac.12230
Conflict of Interest Statement: The authors declare that the research was conducted in the absence of any commercial or financial relationships that could be construed as a potential conflict of interest.

Copyright ( 2019 Pucciariello, Boscari, Tagliani, Brouquisse and Perata. This is an open-access article distributed under the terms of the Creative Commons Attribution License (CC BY). The use, distribution or reproduction in other forums is permitted, provided the original author(s) and the copyright owner(s) are credited and that the original publication in this journal is cited, in accordance with accepted academic practice. No use, distribution or reproduction is permitted which does not comply with these terms. 